\title{
The Effect of the Emo Demo Method on Knowledge, Attitudes, and Actions in Household Waste Sorting in Mamuju District
}

\author{
Agus Erwin Ashari', Abdul Ganing², Zrimurti Mappau ${ }^{3}$, Syamsuddin $^{4}$, \\ Rahmat Haji Saeni ${ }^{5}$ \\ ${ }^{1,2,3}$ Department of Environmental Health, Health Polytechnic, Ministry of Health, Mamuju, Indonesia \\ ${ }^{4}$ Department of Environmental, Health Polytechnic, Ministry of Health, Makassar, Indonesia \\ ${ }^{5}$ Department of Nutrition, Health Polytechnic, Ministry of Health, Mamuju, Indonesia \\ Corresponding Author: Rahmat Haji Saeni
}

DOI: https://doi.org/10.52403/ijhsr.20220206

\begin{abstract}
Background: Waste is one of the most serious environmental problems being faced by people in Indonesia. The waste generated every day mostly comes from household activities as much as $37.3 \%$, both organic and non-organic waste. Waste problems are influenced by many factors, one of which is community behavior, including the resulting waste is even disposed of in various places or burned around the residents' residences, the effect of which will damage the surrounding environment.

Purpose of this study was to determine and analyze the effect of the emo demo method on the knowledge, attitudes, and actions of waste sorting in the district. Mamuju.

Method: This study uses a non-equivalent pre-post test control group design. The sample in this study is housewife in Ex. Binanga as the control group as many as 25 people and Batu Pannu Village as the intervention group as many as 40 people

Results of this study indicate that there are differences in knowledge, attitudes, and actions regarding waste sorting before and after counseling with the emo demo method, there are no differences in knowledge, attitudes, and actions regarding waste sorting before and after counseling with the triggering method.

Conclusions and suggestions in this study are counseling with the emo demo method can increase knowledge, attitudes, and actions in sorting waste, it is suggested to policymakers to be able to use the emo demo method for sanitation programs.
\end{abstract}

Keywords: emo demo, waste sorting, triggering

\section{INTRODUCTION}

Waste is one of the most serious environmental problems being faced by people in Indonesia. Most of the waste generated every day comes from household activities. $37.3 \%$, both organic and nonorganic, have not been managed properly (Ministry of Environment and Forestry (KLHK).

The waste problem is very complex because many factors influence it, one of which is community behavior in waste management[1], this is by the fact that the resulting waste is disposed of in various places or burned around the residents' residences which will damage the surrounding environment. (Devi Hernawati, Choirul Saleh, 2016), Community participation in household waste sorting activities reached $54.8 \%$. [3]. The results showed that most of the $58 \%$ of respondents had good knowledge, while the data on community behavior in the waste sorting process was mostly $71 \%$ did not support the 
waste sorting process. (Harun, 2017). Attitude has a relationship with household waste management. The community needs to increase their awareness of the problem of waste generated by each household, especially regarding the management of household waste.[4]

\section{Emotional Demonstration (Emo}

Demo) is a method of public education through a new approach that refers to the Behavior Centered Design (BCD) theory. BCD theory holds that behavior can only change in response to something new, challenging, surprising, or interesting. This Emo Demo method uses imaginative and creative ways provocative actions to achieve behavior change in the field of public health.[5]

Scientific evidence of the effectiveness of Emo-Demo to change behavior, there are differences in knowledge and practice before and after the CTPS counseling intervention with the emo demo method on school-age children at MI AlBadri Kalisat, Jember Regency. (Amareta, DI, Efri Tri Ardianto ET, 2017 ), there is an effect of the emotional demonstration method on increasing the coverage of weighing toddlers[6] Emo demo is one of the effective health education educations to increase the knowledge and attitudes of mothers under two about exclusive breastfeeding and Child Feeding Portions (Mamonto, CD. Syam, A, Indriasar, R, 2018)

\section{RESEARCH METHODS}

This study uses a non-equivalent pre-post test control group design. In this design, the subjects in the study consisted of two groups, namely an intervention group using the Emo-Demo method and a control group using the triggering method. This research was conducted from July to October 2021 in Batu Pannu Village and Binanga in Mamuju District.

The population in this study were housewives in Mamuju District, the sample was housewives in Binanga village as the control group as many as 25 people and housewives in Batupannu village as the intervention group as many as 40 people.

\section{RESULTS \\ Univariate Analysis}

Table. 1 Distribution of knowledge, attitudes and actions in the intervention group using the Emo Demo method in Batupannu Village, Mamuju 2021

\begin{tabular}{|l|l|l|l|l|l|l|}
\hline Variable & n & mean & variance & SD & Min value-max value \\
\hline Knowledge & Before Counseling & 40 & 9.05 & 9,485 & 3.07 & $2-14$ \\
\cline { 2 - 8 } & After Counseling & 40 & 11.80 & 5.549 & 2.35 & $6-14$ \\
\hline \multirow{2}{*}{ Attitude } & Before Counseling & 40 & 7.175 & 3.53 & 1,879 & $2-10$ \\
\cline { 2 - 7 } & After Counseling & 40 & 8,600 & 1.68 & 1.29 & $5-10$ \\
\hline \multirow{2}{*}{ Action } & Before Counseling & 40 & 4.67 & 4.58 & 2.14 & $1-9$ \\
\cline { 2 - 7 } & After Counseling & 40 & 7.32 & 2.53 & 1.59 & $2-9$ \\
\hline
\end{tabular}

Table. 2 Distribution of knowledge, attitudes, and actions in the Control group with the Triggering method in Binanga Village, Mamuju 2021

\begin{tabular}{|l|l|l|l|l|l|l|}
\hline Variable & n & mean & variance & SD & Min value-max value \\
\hline \multirow{2}{*}{ Knowledge } & Before Counseling & 25 & 13.5 & 2,507 & 1.58 & $8-15$ \\
\cline { 2 - 7 } & After Counseling & 25 & 14 & 1.16 & 1.08 & $11-15$ \\
\hline \multirow{2}{*}{ Attitude } & Before Counseling & 25 & 8.56 & 1.67 & 1.29 & $5-10$ \\
\cline { 2 - 7 } & After Counseling & 25 & 8.76 & 1,607 & 1.27 & $5-10$ \\
\hline \multirow{2}{*}{ Action } & Before Counseling & 25 & 6.00 & 3.66 & 1.91 & $2-9$ \\
\cline { 2 - 7 } & After Counseling & 25 & 6.40 & 2.75 & 1.65 & $2-9$ \\
\hline
\end{tabular}

Based on table 1 shows that the mean difference in knowledge before and after the intervention is 2.75 this is due to the result after the intervention (post-test) of 11.80 which is higher than the value before the intervention (Pre-test) of 9.05. The difference in the mean of waste sorting attitudes is 1.425 this is due to the results after the intervention (post-test) of 8,600 higher than the pre-intervention (Pre-test) value of 7.175 , as well as Waste sorting action after the intervention (post-test) of 
7.32 higher than the pre-intervention (Pretest) value of 4.67 so the mean difference is 2.65 .

Based on table 2, it is revealed that the difference in the mean of waste sorting knowledge is 0.5 , due to the mean at the post-test of 14 and the pre-test of 13.5. The difference in the mean attitude of waste sorting is 0.2. This is due to the post-test mean of 8.76, and the mean of pre-test results being 8.56 and so is the mean of Waste Sorting Action Post-test results of 6.40 which is higher than the post-test value of 6.00 , so the mean difference is 0.40

\section{Bivariate Analysis}

Bivariate analysis was carried out using the Wilcoxon test, after the normality test was carried out, it was known that the data not normally distributed. The Wilcoxon test is intended to analyze the effect of the Emo-Demo method and the Triggering Method of Waste Segregation on changes in knowledge, attitudes and actions of housewives. In this study the measurement of knowledge, attitudes and actions using an instrument (Questionnaire) that has been tested for validity and reliability.

Table 3. Knowledge, attitude and action Waste sorting before and after being given the Emo Demo method in the intervention group in Batupannu Village, Mamuju 2021

\begin{tabular}{|l|l|l|l|l|}
\hline Variable & $\mathbf{n}$ & Mean & P Value \\
\hline Knowledge & Before Counseling & \multirow{2}{*}{40} & 9.05 & \multirow{2}{*}{0.00} \\
\cline { 2 - 2 } & After Counseling & & 11.80 & \\
\hline \multirow{2}{*}{ Attitude } & Before Counseling & 40 & 7.175 & \multirow{2}{*}{0.00} \\
\cline { 2 - 2 } & After Counseling & & 8,600 & \\
\hline \multirow{2}{*}{ Action } & Before Counseling & 40 & 4.67 & \multirow{2}{*}{0.00} \\
\cline { 2 - 2 } & After Counseling & & 7.32 & \\
\hline
\end{tabular}

The results of the statistical test of the bivariate analysis showed a significant value between the mean value before counseling and after counseling and the pvalue $<0.005$, it can be obtained that aThere are significant differences in knowledge, attitudes and actions between before the emo demo method counseling and after the emo demo method counseling

Table 4. Knowledge, attitude and actionWaste sorting before and after being given a triggering method in the control group in Binanga Village. Mamuju 2021

\begin{tabular}{|l|l|l|l|l|}
\hline Variable & & n & Mean & P Value \\
\hline Knowledge & Before Counseling & 25 & 13.5 & 0.272 \\
& After Counseling & & 14 & \\
\hline \multirow{2}{*}{ Attitude } & Before Counseling & 25 & 8.56 & \multirow{2}{*}{0.059} \\
\cline { 2 - 2 } & After Counseling & & 8.76 & \\
\hline \multirow{2}{*}{ Action } & Before Counseling & 25 & 6.00 & 0.058 \\
\cline { 2 - 2 } & After Counseling & & 6.40 & \\
\hline
\end{tabular}

The results of the statistical test of the bivariate analysis showed a significant value between the mean value before counseling with the triggering method and after counseling with the triggering method and the p-value $>0.005$, it can be obtained that there is no There are significant differences in knowledge, attitudes, and actions between before the method counseling trigger with after counseling methods trigger

\begin{tabular}{|c|c|c|c|c|c|c|}
\hline \multirow[t]{2}{*}{ Variable } & \multirow[t]{2}{*}{ Group } & \multirow[t]{2}{*}{$\mathbf{n}$} & \multirow[t]{2}{*}{ Mean Rank } & \multirow[t]{2}{*}{ Sum of Ranks } & \multicolumn{2}{|l|}{ Value } \\
\hline & & & & & $\mathbf{z}$ & Asynp.Sig. (2-tailed) \\
\hline \multirow[t]{2}{*}{ Knowledge } & Intervention Group & 40 & 22.78 & 911.00 & \multirow[t]{2}{*}{-5.560} & \multirow[t]{2}{*}{0.000} \\
\hline & Control Group & 25 & 49.36 & 1234.0 & & \\
\hline \multirow[t]{2}{*}{ Attitude } & Intervention Group & 40 & 27.44 & 1097.50 & \multirow[t]{2}{*}{-3.051} & \multirow[t]{2}{*}{0.002} \\
\hline & Control Group & 25 & 41.90 & 1047.50 & & \\
\hline \multirow[t]{2}{*}{ Action } & Intervention Group & 40 & 28,21 & 1128.00 & \multirow[t]{2}{*}{$-2,615$} & \multirow[t]{2}{*}{0.009} \\
\hline & Control Group & 25 & 40.66 & 1016.50 & & \\
\hline
\end{tabular}

Based on table 5, it is revealed that the average ranking of each group on Waste
Sorting Knowledge, wherein the intervention group the average ranking is 
22.78 lower than the control group, i.e. 49.36. The results of the analysis with the Mann-Whitney $U$ test showed that the statistical value of $\mathrm{Z}$ value was -5.560 and the value of sig (2-tailed) was $0.000<0.05$, therefore the test results were statistically significant, thus we accept Ha, which means there is a difference in knowledge between groups. intervention with the control group.

Based on table 5, it is revealed that the average rank of each group is on the Waste Sorting Attitude, where in the intervention group the average rating is 27.44 lower than the control group, i.e. 41.90. The results of the analysis with the Mann-Whitney $U$ test obtained the statistical value of the $\mathrm{Z}$ value, namely3,051 and the value of sig (2-tailed) is 0.002 $<0.05$, therefore the test results are statistically significant, thus we accept $\mathrm{Ha}$ means There is a difference in attitude between the intervention group and the control group.

Based on table 5 , it is revealed that the average rating of each group in the Waste Sorting Action, wherein the intervention group the average rating is 28.21, lower than the control group, which is 40.66. The results of the analysis with the Mann-Whitney $U$ test obtained the statistical value of the $\mathrm{Z}$ value, namely2,615 and the value of $\operatorname{sig}$ (2-tailed) is 0.009 $<0.05$, because the test results are statistically significant, thus we accept $\mathrm{Ha}$ means there is a difference in actions between the intervention group and the control group

\section{DISCUSSION}

\section{Waste Sorting Knowledge}

The results of the study reveal that there are knowledge differences regarding meaningful waste sorting between before the emo demo method counseling and after the emo demo method counseling in the intervention group, this is in accordance with the research on Health Extension with the Emo Demo Method Effectively Improving the Practice of CTPS at MI AlBadri Kalisat Jember Regency that there are differences in knowledge before and after the CTPS counseling intervention with the emo demo method for school-age children [7], Another study concluded that there was a significant difference between intervention with emo demo [8], as it is stated that there is a difference in the average knowledge of respondents about IMD and exclusive breastfeeding before and after the emo demo and $\mathrm{p}<0.00$.[9], there is an increase in the habit of children washing their hands properly and well after using the emo demo method [10]

In the control group by providing counseling on the triggering method there was no difference in knowledge about Waste Sorting which means that in the first measurement (pre-test) with the second measurement (post-test), this is different from previous research on the effect of the triggering method on changes in open defecation behavior in the people of Kauman Kidul Village, Salatiga City, it was concluded that there was a significant difference between prior knowledge triggering and after triggering.[11], Likewise, other studies concluded that there was an increase in knowledge, PKK cadres in Sesetan Village who received intervention regarding DHF prevention before and after being given triggers (Revelation Adhy Prasetya, 2014)

This research concludes that there is a difference in Knowledge about Waste Segregation between the intervention group and the control group, where the $\mathrm{p}$ value < 0.05 , this is in line with Previous research revealed that there is a difference in the increase in the average score of knowledge, pregnant after being given education on anemia prevention in the emo demo group and the control group [13]

\section{Waste Sorting Attitude}

The results showed that there were significant differences in attitudes about waste sorting between before the Emo Demo Method Counseling and after the Emo Demo Method Counseling in the intervention group[14]. In contrast to other 
studies that from the aspect of attitude there is no significant difference, namely $\mathrm{P}>$ 0.05.[8]

In the control group, it was found that there was no significant difference in attitudes about waste sorting in the first measurement (pre-test) with the second measurement (post-test). receive intervention by triggering method [11], there is an increase in the attitude of PKK cadres regarding DHF prevention after getting DHF triggering compared to before DHF triggering.[12]. This study concludes that there are differences in attitudes about waste sorting between the intervention group and the control group, where the $\mathrm{p}$ value $<0.05$, this is in line with previous research that there are differences in attitudes between the intervention group and the control group. [13]

\section{Waste Sorting Action}

The results showed that there was a meaningful practice of waste sorting between before the Emo Demo Method Counseling and after the Emo Demo Method Counseling in the Intervention group, this is in line with previous research that there was an increase in children's skills by washing hands through the emo demo method [10], There are differences in practice before and after the CTPS counseling intervention with the emo demo method for school-age children at MI AlBadri Kalisat Jember Regency ( $\mathrm{p}=0.000)$ [7].

In the control group, it was found that there was no meaningful action on waste sorting in the first measurement (pre test) with the second measurement (post test), this is different from previous research that there is a significant difference in the practice of respondents regarding open defecation behavior before and after receiving intervention by triggering method[11], there is an increase in the behavior of PKK cadres regarding DHF prevention after getting DHF triggering compared to before DHF triggering [12]

This study also concludes that there are differences in measures regarding waste segregation between the intervention group and the control group, where the $p$ value $<0.05$, this is in accordance with the research which revealed that there are differences in the behavior of anemia prevention in pregnant women in the treatment group and the control group.[13]

\section{CONCLUSION}

There are differences in knowledge, attitudes, and actions regarding waste sorting before and after counseling with the emo demo method

The intervention carried out in the form of counseling using the emo demo method proved that there were differences in knowledge, attitudes, and actions of sorting waste in the intervention group and the control group.

\section{Acknowledgement: None}

Conflict of Interest: None

\section{Source of Funding: None}

\section{Ethical Approval: Approved}

\section{REFERENCES}

1. F. Nuraisyah, S. Solikhah, and R. Rilyandari, "Pengetahuan, sikap dan perilaku masyarakat dalam pemilahan dan pengolahan sampah," J. community Serv. Res., vol. 5, no. 2, pp. 58-61, 2021.

2. S. Devi Hernawati, Choirul Saleh, "Partisipasi Masyarakat Dalam pengelolaan Sampah Berbasis 3R P 3R (Reduce, Reuse dan Recycle) (Studi Pada Tempat Pengelolaan Sampah Terpadu Di Desa Multoagung Kecamatan Dau Kabupaten Malang)," J. Adm. Publik, vol. 1, no. 2, pp. 181-187, 2016.

3. S. Zulkarnaini and Z, "Faktor-faktor penentu tingkat partisipasi pedagang dalam pengelolaan sampah di pasar pagi arengka kota pekanbaru," J. Ilmu Lingkung., vol. 3, no. 1, pp. 1-11, 2009.

4. R. H. A. Fara Marwa Sumah, JootjeM.L.Umboh, "Hubungan Antara Pengetahuan Dan Sikap Dengan Tindakan Ibu Rumah Tangga Dalam Pengelolaan Sampah Rumah Tangga Di Lingkungan Ii 
Kelurahan Istiqlal Kecamatan Wenang Kota Manado Tahun 2013," J. Kesehat. Lingkung., vol. 1, no. 3, pp. 1-6, 2013.

5. Global Alliance for Improved Nutrition (GAIN), Buku Panduan pelatihan untuk Master Pelatih (MoT). 2016.

6. I. Ermawati, W. Yuliana, and B. Hakim, "Pengaruh Emotional Demonstration peningkaan Cakupan Penimbangan Balita Posyandu," J. Ilm. Kesehat., vol. 13, no. 2, pp. $165-171,2020$.

7. D. I. Amareta and E. T. Ardianto, "Penyuluhan Kesehatan dengan Metode Emo Demo Efektif Meningkatkan Praktik CTPS di MI Al-Badri Kalisat Kabupaten Jember," pp. 246-250, 2017.

8. A. Intiyanti and Juliana, Pengaruh Pengembangan Metode Emo Demo Terhadap Perilaku Pemberian MP ASI Pada Ibu BADUTA di Kota Surabaya, vol. 53, no. 9. 2019.

9. V. R. S. Renny Sinaga, "Emotional demonstration (emo demo)efektif meningkatan pelaksanaan imd dan pemberian asi ekslusif pada ibu hamil," $J$. Ilm. Pannmed, vol. 15, no. 1, pp. 345-351, 2020.

10. N. K. Aziz, H. Khotimah, S. A. Andayani, and $\mathrm{H}$. Wahid, "Metode Emo Demi dan Metode Bermain Pizzle Terhadap Cara Mencuci Tangan Pada Anak Prasekolah," Community Publ. Nurs., vol. 7, no. April, pp. 35-44, 2019.

11. Y. H. D. Pudjaningrum, Nur Endah Wahyuningsih, "Pengaruh Metode Pemicuan Terhadap Perubahan Perilaku buang Air Besar Sembarangan pada Masyarakat kelurahan Kauman Kidul Kota
Salatiga," J. Kesehat. Masy., vol. 4, no. 5, pp. 100-108, 2016.

12. D. P. Y. K. Wahyu Adhy Prasetya, "Pengaruh Pemicuan Masalah Demam Berdarah Berbasis Masyarakat Terhadap Pengetahuan, Sikap, Dan Perilaku Pencegahan DBD Pada Kader PKK Di Kelurahan Sesetan Tahun 2013," Community Health (Bristol)., vol. II, no. 1, pp. 63-73, 2014, doi: 10.1093/oxfordhb/9780195342819.013.003 1.

13. M. Yanik and F. Aulia, "Pengaruh Permainan Emo Demo Atika (Ati, Telur Ikan) Terhadap Pengetahuan, Sikap dan Tingkah Laku Terhadap Pengeahuan, Sikap dan Tingkah Laku Pencegahan Anemia Pada Ibu Hamil," J. Ilmu Keperawatan dan Kebidanan, vol. 12, no. 2, pp. 222-228, 2021.

14. C. D. Mamonto, A. Syam, and R. Indriasari, "Edukasi Emotional Demonstration Tentang Pemberian Makan Anak Terhadap Tingkat Pengetahuan dan Sikap Ibu Baduta Emotional Demonstration Education About Child Feeding on the Level of Knowledge and Attitude of Baduta Mothers Chindra Dewi Mamonto , Aminuddin,” vol. 1, 2019.

How to cite this article: Agus Erwin Ashari, Abdul Ganing, Zrimurti Mappau et.al. The effect of the emo demo method on knowledge, attitudes, and actions in household waste sorting in Mamuju District. Int J Health Sci Res. 2022; 12(2): 51-56. DOI: https://doi.org/10.52403/ ijhsr.20220206 